\title{
STUDY OF TELLURIUM-129m (129mTe) GROUND DEPOSITION FOLLOWING FUKUSHIMA NUCLEAR DISASTER: DESCRIPTIVE ANALYSIS OF UNSCEAR DATABASE USING STATISTICAL PROCESS TECHNIQUES
}

\author{
*Mostafa ESSAM EISSA, Cairo University, Faculty of Pharmacy (independent Researcher Category), Cairo, Egypt, \\ mostafaessameissa@yahoo.com \\ (iD) https://orcid.org/0000-0003-3562-5935) \\ Engy REFAAT RASHED, National Centre for Radiation Research and Technology, Cairo, Egypt, engyrefaat@yahoo.com \\ (iD https://orcid.org/0000-0002-6593-378X) \\ Dalia ESSAM EISSA, Royal Oldham Hospital, Oldham, United Kingdom, eissade@yahoo.com
}

(iD) https://orcid.org/0000-0002-6340-8973)

Received: 22.06.2021, Accepted: 30.12.2021

*Corresponding author DOI: $10.22531 /$ muglajsci.955946

\section{Abstract}

One of the most shocking accidents that have impacted the world recently was the devastation of the Fukushima-Daiichi nuclear power plant following a major earthquake followed by a strong 15-meter Tsunami wave affecting the east coast region. One of the major adverse consequences of this catastrophic event is the release and dissemination of radioactive materials in the surrounding environment. Tellurium-129m is one of the comprehensively traced fission products to assess the magnitude of spreading by measuring ground soil deposition of radioactivity. Radiation level/location relationship study was tested using a simple and inexpensive statistical software package using unique Statistical Process Control methodologies for the United Nations Scientific Committee on the Effects of Atomic Radiation database that demonstrated spiking in radioactivity. Sampling points were geographically associated with the radioactivity level with the spot of the maximum radionuclide concentration could be linked with the damaged plant location. More than three-fifths of the measured radioactivity are confined in an area of about $640 \mathrm{~km}^{2}$ covering five municipalities namely Namie, and Futaba towns, Litate village and Iwaki city. The latitude-oriented chart showed a sudden rise in deposition followed by a gradual decline. Excessive Tellurium-129m activity could be observed in the area of the catastrophic event.

Keywords: Control Chart, Fukushima, Tellurium, Pareto, PCA

\section{FUKUSHIMA NÜKLEER AFETININ ARDINDAN TELLURIUM-129m (129mTe) ZEMİN BİRIKTIRME ÇALIŞMASI: İSTATISTIKSEL İŞLEM TEKNIKLERI KULLANILARAK UNSCEAR VERITTABANININ TANIMLAYICI ANALIZİ}

\section{Özet}

Son zamanlarda dünyayı etkileyen en şok edici kazalardan biri, büyük bir depremin ardından Fukushima-Daiichi nükleer Son zamanlarda dünyayı etkileyen en şok edici kazalardan biri, büyük bir depremin ardından Fukushima-Daiichi nükleer santralinin yıkılması ve ardından doğu kıyı bölgesini etkileyen 15 metrelik güçlü bir Tsunami dalgasıydı. Bu felaket olayının en büyük olumsuz sonuçlarından biri, radyoaktif maddelerin çevredeki ortamda salınması ve yayılmasıdır. Tellurium$129 m$, toprakta radyoaktivite birikimini ölçerek yayılmanın büyüklüğünü değerlendirmek için kapsamlı bir şekilde izlenen fisyon ürünlerinden biridir. Radyasyon seviyesi/konum ilişkisi çalışması, radyoaktivitede ani artış gösteren Birleșmiș Milletler Atomik Radyasyonun Etkileri veri tabanı için benzersiz İstatistiksel Proses Kontrol metodolojileri kullanılarak basit ve ucuz bir istatistiksel yazılım paketi kullanılarak test edildi. Numune alma noktaları, radyoaktivite seviyesi ile coğrafi olarak ilişkilendirildi ve maksimum radyonüklid konsantrasyonunun bulunduğu nokta, hasarlı bitki konumu ile ilişkilendirilebilir. Ölçülen radyoaktivitenin beşte üçünden fazlası, Namie ve Futaba kasabaları, Litate köyü ve Iwaki şehri olmak üzere beş belediyeyi kapsayan yaklaşık $640 \mathrm{~km}^{2}$ 'lik bir alanla sınırlıdır. Enlem odaklı grafik, birikimde ani bir artış ve ardından kademeli bir düşüş gösterdi. Felaket olayının olduğu bölgede aşırı Tellurium-129m aktivitesi gözlemlenebilir.

Anahtar Kelimeler: Kontrol Tablosu, Fukushima, Tellür, Pareto, PCA

Cite

Eissa, M. E., Rashed, E. R., Eissa, D. E., (2021). “Study of Tellurium-129m (129mTe) Ground Deposition Following Fukushima Nuclear Disaster: Descriptive Analysis of UNSCEAR Database Using Statistical Process Techniques", Mugla Journal of Science and Technology, 7(2), 67-72. 


\section{Introduction}

In modern human history, few events of nuclear catastrophes have occurred which resulted from accidents associated with human errors, malfunctions and natural devastating phenomena [1, 2]. The consequences of catastrophic nuclear accidents are of great concern due to their impact on the environment and the ecosystem. The leakage of the radioactive materials from the reactors occurs with a variable degree of spreading.

One of the most likely released indicators of the fission products (FP: s) is the volatile material of tellurium [3]. Special focus on this FP is due to its high volatility nature and highly reactive character [4]. Thus, an assessment of tellurium deposition around the leaking source region would give a reasonable indication of the magnitude of the FP: s spreading in the affected area.

Tellurium was discovered in the late $18^{\text {th }}$ century (1782) by Müller [5]. Its presence as a trace constituent ( $2 \mathrm{ppb}$ ) in the Earth's crust is comparable to the abundance of platinum [6]. Tellurium is one of the chalcogens which are chemical elements in group 16 of the periodic table. This group is also known as the oxygen family [7]. It consists of the elements oxygen (O), sulfur (S), selenium (Se), tellurium (Te), and the radioactive element polonium (Po) [7]. Tellurium-129m belongs to the medium-high toxicity radionuclides class [8].

A radionuclide (radioactive nuclide, radioisotope or radioactive isotope) is an atom that has excess nuclear energy, making it unstable. The atomic structure of tellurium comprises 52 protons and 77 neutrons with $11 / 2$ - nuclear spin and parity. This excited nuclear isomer has a half-life of 33.6(1) d [9]. ${ }^{129 m}$ Te have an excitation energy of $105.50(5) \mathrm{keV}$. The daughter isotopes are ${ }^{129} \mathrm{I}$ and ${ }^{129} \mathrm{Te}$ with a decay mode of $\beta-(36 \%)$ and Isomeric Transition (IT) (64\%), respectively [10, 11].

A metastable form of tellurium was reported in the disaster area of the Fukushima nuclear power plant which was impacted by a massive Tsunami wave attack that flooded the coastal region [12]. The study of the distribution of $129 \mathrm{~m}$ Te deposition concentration would be useful to analyze and study the level of spreading of the FP: s post-disaster event. The present work would provide descriptive analysis for radiation-location relation in a quantitative manner using statistical process methodologies. This investigation would focus on the geographical and terrain distribution of tellurium$129 \mathrm{~m}$ in Japan post Tsunami that damaged the Fukushima-Daiichi Nuclear Power Station.

\section{Material and Methods}

The United Nations Scientific Committee on the Effects of Atomic Radiation (UNSCEAR) web platform provides an Excel-based database for radionuclide concentration, coordinates and municipal distribution from which a $129 \mathrm{~m}$ Te dataset could be obtained. Raw data were isolated and stratified for further processing [13]. Measurement of radiation level per unit surface area $\left(\mathrm{m}^{2}\right)$ is expressed as becquerel where one becquerel (one $\mathrm{Bq}$ ) equals one disintegration of atom per second (one $\mathrm{Ci}=37 \mathrm{GBq}$ ). The official organization site is http://www.unscear.org/unscear/index.html. Data analysis and interpretation were conducted using Minitab ${ }^{\circledR}$ version 17.1.0 [14]. Sample size for each location varies from one to five readings.

\subsection{Geographical Radiation Distribution Analysis}

Coordinates' columns were arranged on the ascending order of latitude as a primary classifier followed by longitude in the secondary order. The arranged sheet of coordinates was translated into map location assigned spots.

\subsubsection{Contour Plot [15]}

Two-dimensional illustration of three variables where ${ }^{129 m}$ Te concentration ( $\mathrm{z}$ variable is expressed as $\mathrm{Bq} / \mathrm{m}^{2}$ ) is a function of latitude ( $\mathrm{x}$ ) and longitude $(\mathrm{y})$ as given in the equation (1) below.

$$
z=f(x, y)
$$

According to the database, the sampling of soils was performed from 6 June 2011 to 8 July 2011 at depth of five centimeters in the soil. The replicate sampling may vary but does not exceed five samples.

\subsubsection{Pareto Analysis [16]}

Pareto charting is implemented to identify municipalities with the greatest impact of radiation following the rule $80 / 20$ rule in descending order in the magnitude of the average radiation readings. The analysis shows the individual contribution of radiation concentration percent for each location as well as cumulative (\%) up to about $80 \%$.

\subsection{Histogram Distribution of $129 \mathrm{~m}$ Te}

The distribution pattern of $129 \mathrm{~m}$ Te radiation concentration level is assessed through a histogram. The readings range is divided into intervals (bins) where the frequency is determined in each to show the spreading of the dataset for the regional radiation level [17].

\subsection{Coordinate-Oriented Trending Plot [18]}

A process-behavior diagram was plotted taking into consideration the principle of Laney-correction for over or under-dispersion of data [19]. The coordinatedarranged record was drawn with regard to the number of readings per point. The chart consists of the mean (M), Upper Control Limit (UCL) and Lower Control Limit (LCL) to plot the pattern of the radiation with the respect to the latitude and longitude axis.

\section{Results and Discussion}

Implementation of Statistical Process Control (SPC) techniques has gained wide interest and application in both industrial as well as non-industrial fields, including various events and phenomena [20-23]. SPC methodologies have the advantage of visualization of the 
pattern, trend and behavior of the inspection properties under investigation. In the case of a catastrophic event, this analysis may be crucial for learning lessons and taking appropriate measures for future situations. The implemented tools are fast, simple, time-saving and inexpensive.

\subsection{Geographical Distribution and Radiation Level}

Sampling locations post-Fukushima-Daiichi nuclear disaster - in Honshu island - have been translated visually from the database Ōkuma and Futaba in Fukushima Prefecture into a map (Figure 1) showing the affected east coast in Japan on the Pacific Ocean by the radiation spreading [24, 25].

The area of the maximum radioactivity with spiking in the measurement coincides with the location of the devastating plant of $37^{\circ} 25^{\prime} 23^{\prime \prime} \mathrm{N}$ and $141^{\circ} 01^{\prime} 59$ " E as could be seen from the contour plot in Figure 2 $[26,27]$. On the other hand, major contributors of radionuclide based on the municipality are shown in Figure 3 through Pareto analysis.

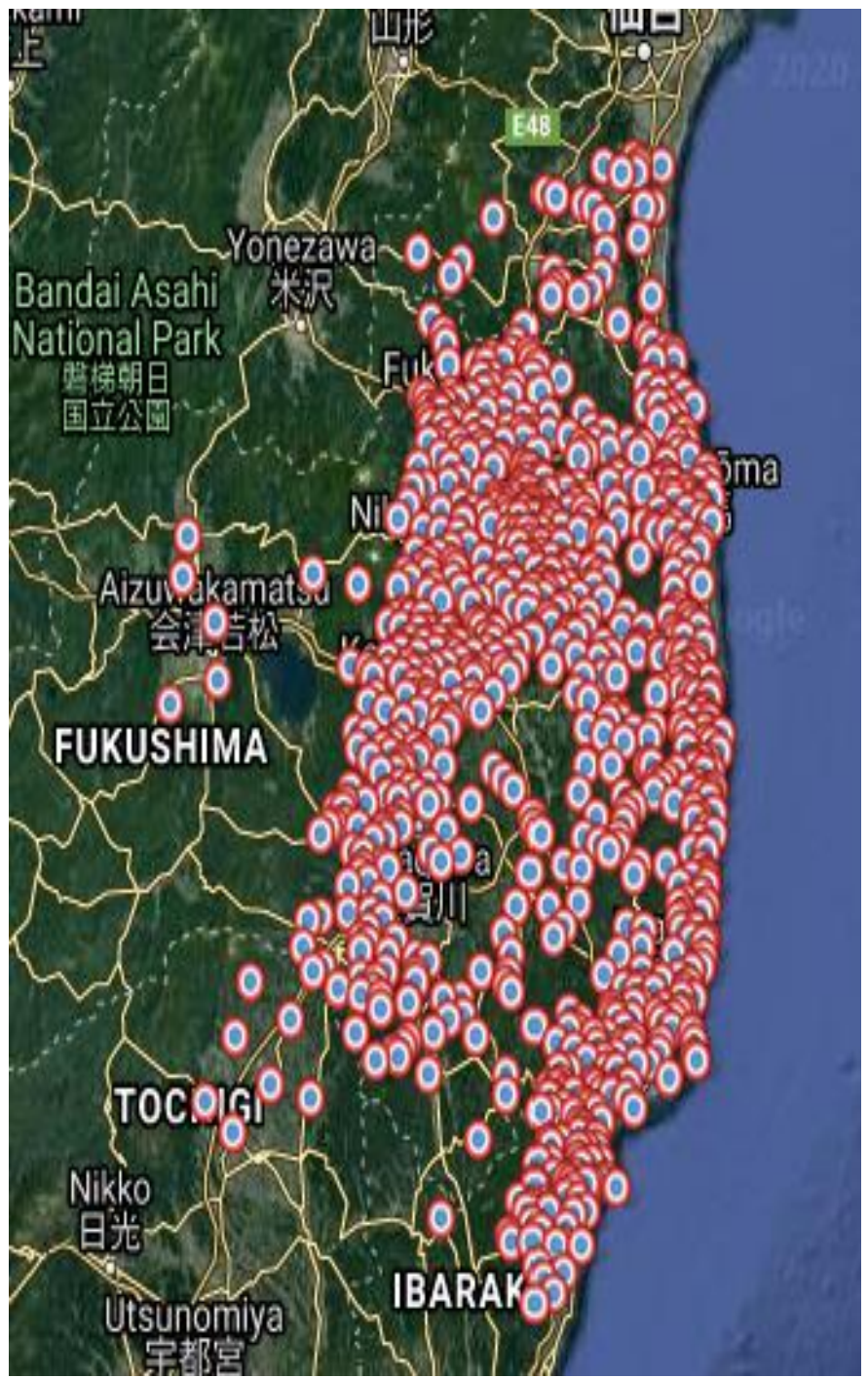

Figure 1. Location map for sampling site for ${ }^{129 \mathrm{mTe}}$ measurement.
Contour Plot of Average $129 \mathrm{mTe} B$ vs Latitude \& Longitude

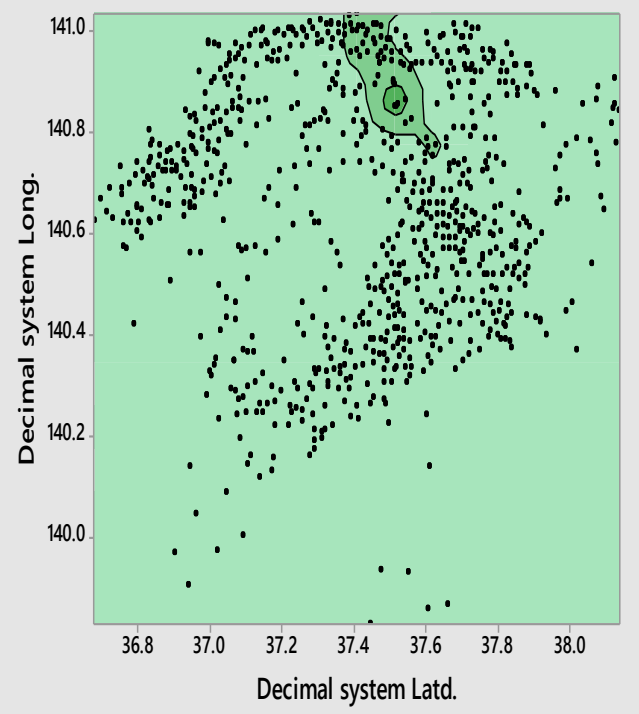

Figure 2. Coordinates-radioactivity plot of $129 \mathrm{mTe}\left(\mathrm{as} \mathrm{Bq} / \mathrm{m}^{2}\right)$.

More than $60 \%$ of the radioactivity could be demonstrated by only five regions: Namie $\left(37.4955^{\circ} \mathrm{N}\right.$, $\left.141.0017^{\circ} \mathrm{E}\right)$, Okuma $\left(37.4045^{\circ} \mathrm{N}, 140.9834^{\circ} \mathrm{E}\right)$ and Futaba $\left(37.4492^{\circ} \mathrm{N}, 141.0124^{\circ} \mathrm{E}\right)$ towns, Litate village $\left(37.6783^{\circ} \mathrm{N}, 140.7360^{\circ} \mathrm{E}\right)$ and Iwaki city $\left(37.0505^{\circ} \mathrm{N}\right.$, $140.8877^{\circ}$ E) [28]. Thus, the coordinates of the major radiation activity range from 37.0505 to $37.6783^{\circ} \mathrm{N}$ and from 140.7360 to $141.0124^{\circ} \mathrm{E}$.

Based on Penta-vertices coordinates reference, the estimated area of $640.11 \mathrm{~km}^{2}$ approximately with a perimeter of about $172.44 \mathrm{~km}$ was the source of about $62 \%$ of the total screened $129 \mathrm{~m}$ Te radioactivity.

\subsection{Histogram Interpretation}

The lower data-bound of zero gives the shape of a positively skewed histogram [29]. A positively skewed histogram suggests the mean is greater than the median. More of the data is towards the left-hand side of the distribution, with a few aberrant radionuclide concentration values to the right due to high radiation levels ( $>81 \%$ from the total samples) in ten municipal locations. Accordingly, the pattern demonstrated apparently remote outlier values of the Tellurium $-129 \mathrm{~m}$ ground deposition radioactivity. However, the goodnessof-fit test shows that there is no distribution that adequately describes the dispersion pattern of this dataset at $\mathrm{p}=0.05$.

\subsection{Process-Behavior Chart for Radioactivity Trending}

Control chart was established based on ascending latitude as a reference frame with sub-classification according to an ascending longitude value [19]. In the monitoring of the trending behavior of the inspection characteristic, two types of fluxes could be isolated: assignable and common cause variations. Two alarming special-cause variations - indicated by red dots - could be spotted " 1 " and " 2 " for the extraneous abnormal and 
average shift of the observed inspection characteristic, respectively [30]. Since subgroup measures are not equal, the UCL is not fixed, instead, it is fluctuating [31, 32]. Major excursions in Figure 6 that greatly exceeded the mean and the UCL lines are confined almost within $37.3696 \mathrm{~N}^{\circ}$ and $37.6353 \mathrm{~N}^{\circ}$, with an abrupt rise in the deposited radiation level followed by a gradual decline to the stable base value.

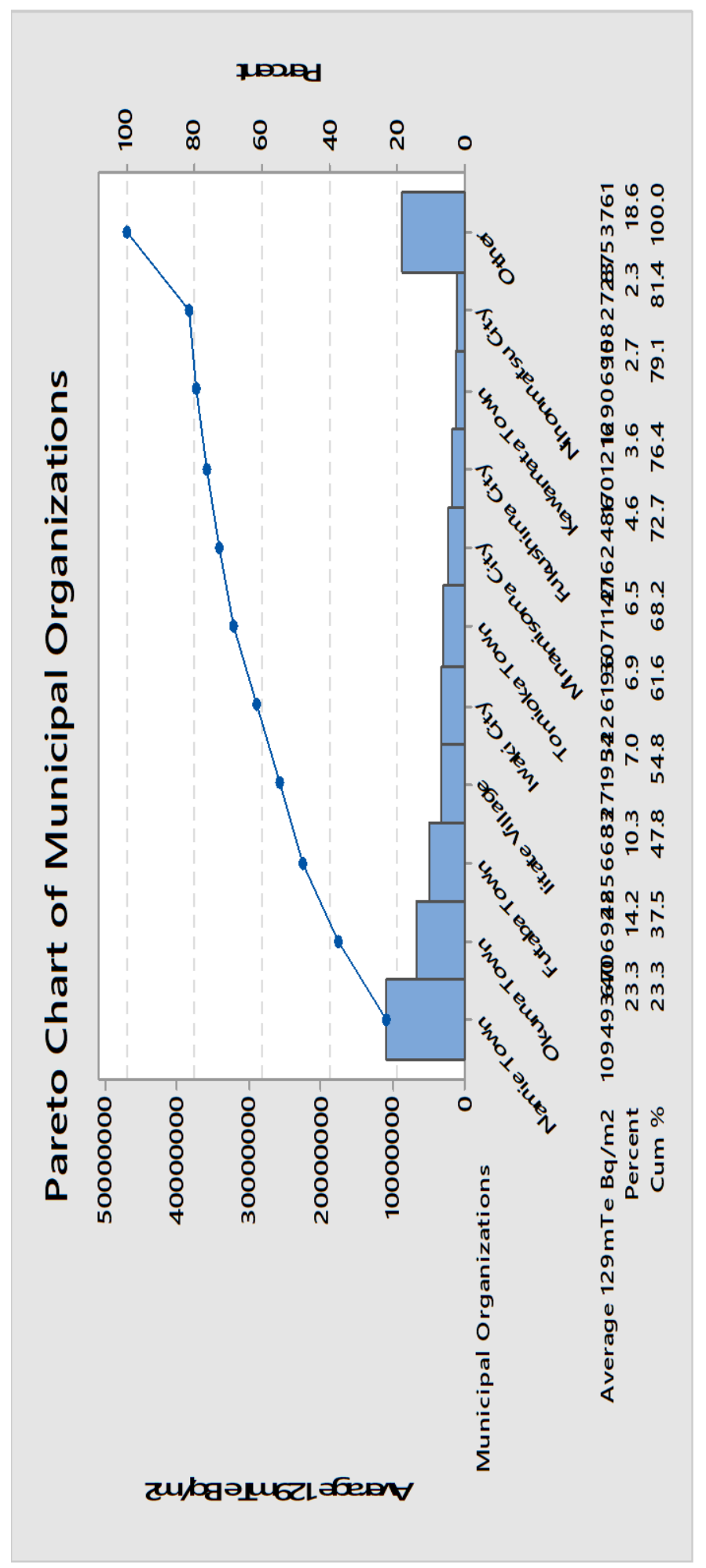

Figure 3. Pareto diagram of major contributors' regions of the radioactivity detection in samples.

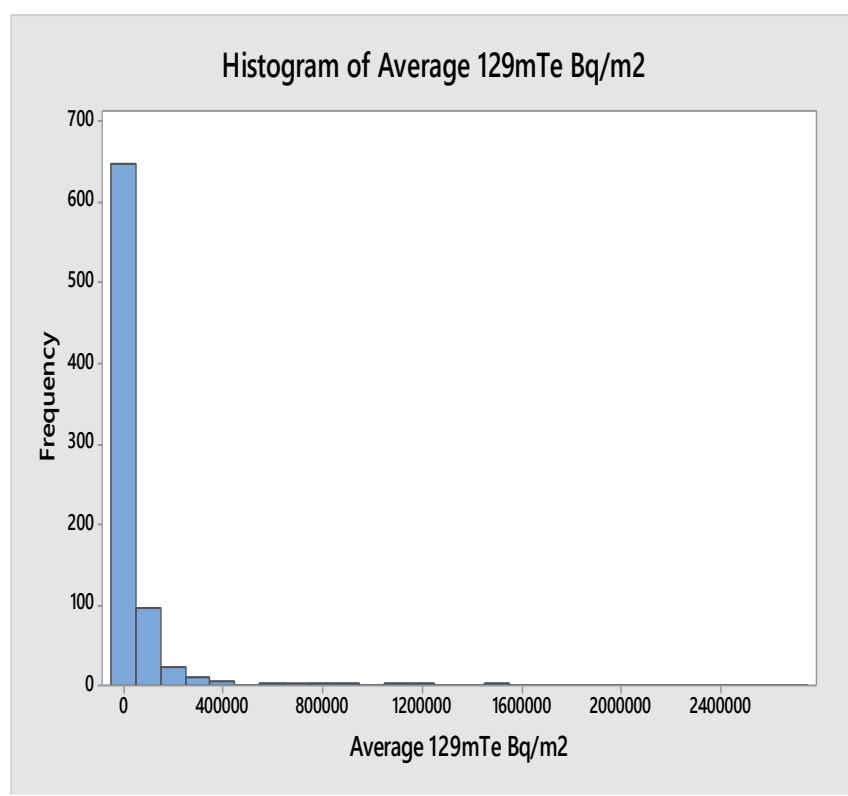

Figure 4. Histogram plot of the dispersion pattern of radioactivity readings in the screened region

\subsection{Combination Overview Analysis}

The study presented herein showed the implementation of simple, fast and inexpensive SPC tools in the study of disasters where considering time factor is crucial for rapid quantitative assessment of the major impacted zones. Contour plot translated the map into a locationmagnitude of radiation deposit relationship in visual presentation. On the other hand, Pareto plot convert these locations into the major municipal contribution in terms of radioactivity of $129 \mathrm{mTe}$. Finally, the trending profile of the Tellurium-129m (as Bq/m2) - in x-axis - for each studied location has been assessed with ascending coordinate reference using latitude as a primary classifier followed by longitude sub-classification. Through the combination of these techniques, it is possible to identify the major spots of the radioactivity in the soil. This would help in resources management and hazard mitigation through appropriate knowledge of the major impacted regions of the disaster area. 


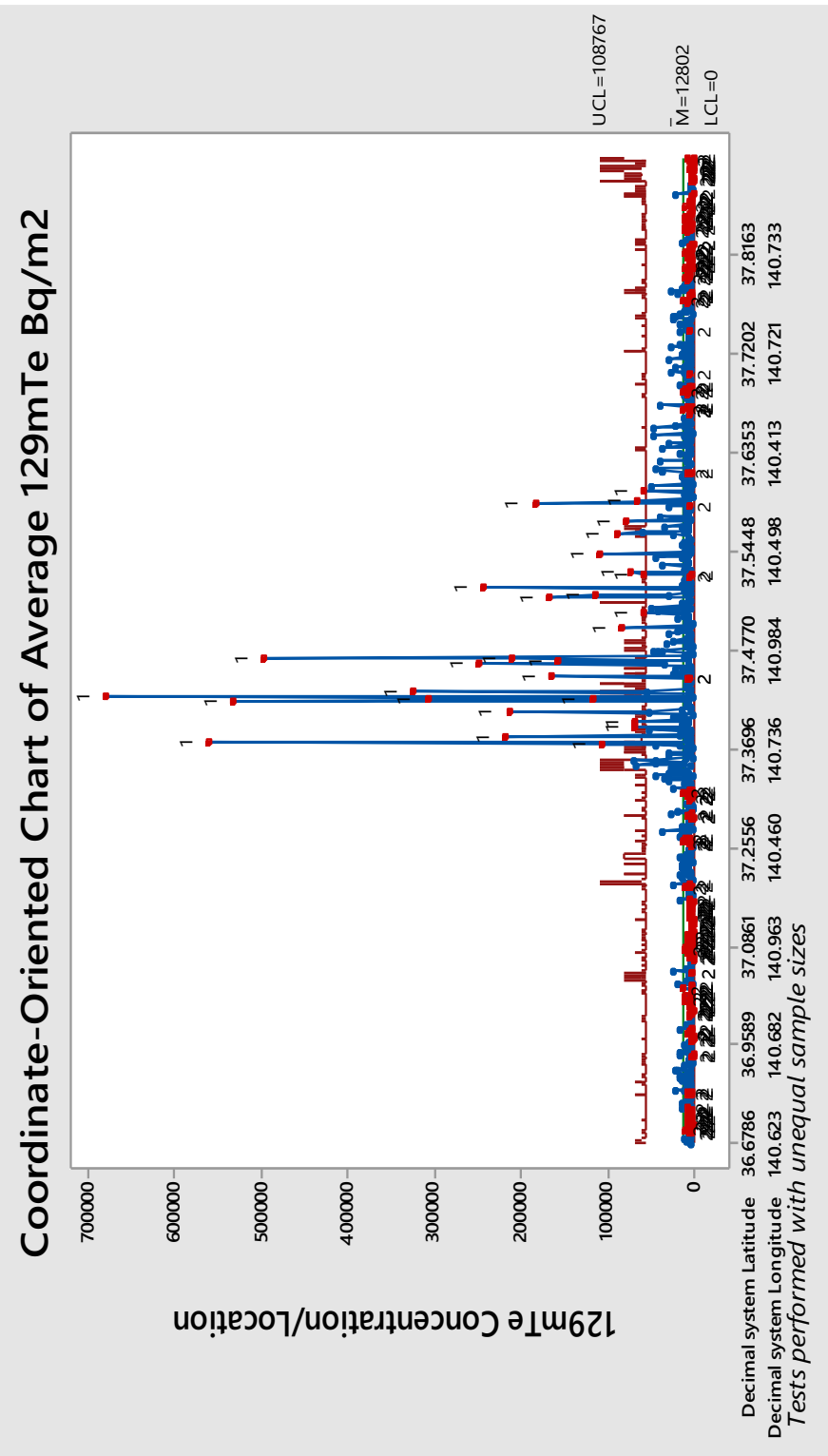

Figure 6. Coordinate-oriented trending chart of $129 \mathrm{mTe}$ radiation behavior following nuclear power plant disaster.

\section{Conclusion}

Implementation of SPC methodologies demonstrated advantageous quantitative evaluation of the nuclear accident for the sake of the post-catastrophic analysis. ${ }^{129 \mathrm{~m} T e}$. The present study showed that the major radionuclide activity for Fukushima-Daiichi - a boiling water reactor (BWR) - nuclear disaster of more than $60 \%$ is confined theoretically in a radius of about $14 \mathrm{~km}$ which embrace a location of $37.4045^{\circ} \mathrm{N}, 140.9834^{\circ} \mathrm{E}$ of the damaged power plant. In this work, unique application of the control chart was used through using coordinatebased order of the radiation level deposition, instead of the chronological order of the event. The future perspective of this research may include other indicator radioisotope species and their correlation, in addition to the multivariate study.

\section{References}

[1] Bohanec, M., Ivan, V., Ivica, B., Klemen, D., and Luka S., "Conceptual design of a decision support tool for severe accident management in nuclear power plants." PhD diss., Institut Jožef Stefan, 2019.

[2] Yablokov, A.V., Nesterenko, V.B. and Nesterenko, A.V. (Editor, Sherman-Nevinger, J.D.), Chernobyl: Consequences of the Catastrophe for People and the Environment (Vol. 39). Blackwell Publishing for the Annals of the New York Academy of Sciences, Boston, MA, 2010.

[3] Espegren, F. and Ekberg, C., "Potential tellurium deposits in the BWR containment during a severe nuclear accident", Annals of Nuclear Energy, 146, p.1076292020, 2020.

[4] Pontillon, Y. and Ducros, G., "Behaviour of fission products under severe PWR accident conditions: The VERCORS experimental programme-Part 2: Release and transport of fission gases and volatile fission products", Nuclear engineering and design, 240(7), 1853-1866, 2010.

[5] Weeks, M.E., "The discovery of the elements. VI. Tellurium and selenium". Journal of Chemical Education, 9(3), 474, 1932.

[6] He, Z., Yang, Y., Liu, J.W. and Yu, S.H., "Emerging tellurium nanostructures: controllable synthesis and their applications", Chemical Society Reviews, 46(10), 2732-2753, 2017.

[7] Kar, S., "Optical and Structural Studies of Binary Compounds by Explosive Laser Irradiation and Heat Treatment", Nanocomposites with Unique Properties and Applications in Medicine and Industry, 267, 2011.

[8] Atomic Energy Research Institute (KACST), General Instructions on Protection against Ionizing Radiations In The Kingdom of Saudi Arabia, King Abd al-Aziz City for Science and Technology, Kingdom of Saudi Arabia, 2007.

[9] Alessandrello, A., Arnaboldi, C., Brofferio, C., Capelli, S., Cremonesi, O., Fiorini, E., Nucciotti, A., Pavan, M., Pessina, G., Pirro, S., Previtali, E., Sisti, M., Vanzini, M., Zanotti, L., Giuliani, A., Pedretti, M., Bucci, C. and Pobes, C., "New limits on naturally occurring electron capture of ${ }^{123} \mathrm{Te}$ ", Physical Review C, 67(1), 2003.

[10] Meija, J., Coplen, T., Berglund, M., Brand, W., De Bièvre, P., Gröning, M., Holden, N., Irrgeher, J., Loss, R., Walczyk, T. and Prohaska, T., "Atomic weights of the elements 2013 (IUPAC Technical Report)", Pure and Applied Chemistry, 88(3), 265-291, 2016.

[11] Auranen, K., Seweryniak, D., Albers, M., Ayangeakaa, A., Bottoni, S., Carpenter, M., Chiara, C., Copp, P., David, H., Doherty, D., Harker, J., Hoffman, C., Janssens, R., Khoo, T., Kuvin, S., Lauritsen, T., Lotay, G., Rogers, A., Sethi, J., Scholey, C., Talwar, R., Walters, W., Woods, P. and Zhu, S., "Superallowed $\alpha$ Decay to Doubly Magic Sn100", Physical Review Letters, 121(18), 2018.

[12] Fukumoto, M., Low-Dose Radiation Effects on Animals and Ecosystems. Amsterdam University Press, Singapore, 2020.

[13] Silini, G., "The United Nations Scientific Committee on the Effects of Atomic Radiation (UNSCEAR)", Radiation Protection Dosimetry, 1(4), 261-262, 1981. 
[14] Parthasarathy, R., "Applied Statistics Manual: A Guide to Improving and Sustaining Quality with Minitab", Quality Progress, 52(8), 62-62, 2019.

[15] Cintas, P.G., Marco-Almagro, L. and Llabres, J.T.M., Industrial statistics with Minitab. Hoboken: Wiley, Barcelona, 2012.

[16] Henderson, G.R., Six Sigma quality improvement with MINITAB. John Wiley \& Sons, West Sussex, 2011.

[17] Lesik, S.A., Applied statistical inference with MINITAB ${ }^{\circledR}$. CRC Press, Boca Raton, 2018.

[18] Eissa, M. and Rashed, E., "Unique Quantitative Analysis of Tsunami Waves using Statistical Software: A Case Study of The Major Recorded Hawaii Incidents". Advanced Materials Proceedings, 6(1), 21010419-21010419, 2021.

[19] Eissa, M.E., "Application of Laney control chart in assessment of microbiological quality of oral pharmaceutical filterable products", Bangladesh Journal of Scientific and Industrial Research, 52(3), 239-246, 2017.

[20] Eissa, M.E., 2019. "Use of Control Charts as a Quality Control Tool for Monitoring of Microbiological Infection Risk during Surgery: An Expository Case". Clinical Journal of Surgery, 2(1), 1-3, 2019.

[21] Eissa, M. and Rashed, E., "Inventory Digital Management Using Statistical Process Control Analysis in Healthcare Industry", Dijital Çă̆da Issletmecilik Dergisi, 3(2), 123-128, 2020.

[22] Eissa, M., "The attribute control charts for outbreak trends of selected states in the USA: a brief report of the insight into the pattern", Int. Med., 1(1), 11-4, 2019.

[23] Eissa, E. and Abdoh, M., "Evaluation of quality characteristics and process stability for pharmaceutical dosage form using attribute control charts", International Journal of Advances in Medical Sciences, 09-15, 2020.

[24] Komissarov, M. and Ogura, S.I., "Siltation and radiocesium pollution of small lakes in different catchment types far from the Fukushima Daiichi nuclear power plant accident site", International Soil and Water Conservation Research, 8(1), 56-65, 2020.

[25] Mabon, L., "Enhancing post-disaster resilience by 'building back greener': Evaluating the contribution of nature-based solutions to recovery planning in Futaba County, Fukushima Prefecture, Japan", Landscape and urban planning, 187, 105-118, 2019.

[26] Mikami, S., Maeyama, T., Hoshide, Y., Sakamoto, R., Sato, S., Okuda, N., Demongeot, S., Gurriaran, R., Uwamino, Y., Kato, H. and Fujiwara, M., "Spatial distributions of radionuclides deposited onto ground soil around the Fukushima Dai-ichi Nuclear Power Plant and their temporal change until December 2012", Journal of environmental radioactivity, 139, 320-343, 2015.

[27] Sun, D., Wainwright, H.M., Oroza, C.A., Seki, A., Mikami, S., Takemiya, H. and Saito, K., "Optimizing long-term monitoring of radiation air-dose rates after the Fukushima Daiichi Nuclear Power Plant", Journal of environmental radioactivity, 220, 106281, 2020.

[28] Yonemoto, K., "Changes in the input-output structures of the six regions of Fukushima, Japan: 3 years after the disaster", Journal of Economic Structures, 5(1), 1-20, 2016.

[29] Saito, H. and Goovaerts, P., "Geostatistical interpolation of positively skewed and censored data in a dioxin-contaminated site", Environmental Science \& Technology, 34(19), 4228-4235, 2000.

[31] Eissa, M.E., Seif, M. and Fares, M., "Assessment of purified water quality in pharmaceutical facility using six sigma tools" International Journal of Pharmaceutical Quality Assurance, 6(02), 54-72, 2015.

[32] Nelson, L.S., "Shewhart control charts with unequal subgroup sizes", Journal of Quality Technology, 26(1), 64-67, 1994. 